\title{
Measuring fluoride in human saliva and water
}

\section{Abstract}

Background and objective: Fluoride is used to prevent dental caries, and it has been one of the most effective and widespread agents. Fluoride level has been shown in saliva, plaque, and oral soft tissues after use of fluoridated toothpaste that persists at potentially active concentrations for hours. This study aimed to evaluate how fluoride in toothpaste intake can affect the salivary fluoride and test fluoride in tap water in the different places of Erbil city.

Methods: Forty five volunteers were examined. In the morning after overnight fasting before brushing teeth, the saliva of the subjects (healthy non-smoker adults) was taken before brushing teeth, which was a baseline. After 10 and 20 minutes of washing mouth with water (after brushing), saliva was taken and then the cotton pad was held under the tongue for $5 \mathrm{~min}$. Saliva samples were frozen at $-20 \mathrm{C}^{\circ}$ for later analysis. Tap water samples in different places in Erbil city were analyzed.

Results: Toothpaste significantly $(P=0.002)$ increased salivary fluoride after brushing teeth. The fluoride concentration of tap water in Erbil city was very low at the places that use groundwater.

Conclusion: This research indicates that salivary fluoride significantly increases after brushing teeth. The fluoride concentration naturally occurring levels in the tap water in the places where the source is groundwater are not enough.

Keywords: Fluoride; Dental caries; Saliva.

\section{Introduction}

Fluorine is a common element because of its high reactivity does not occur in the elemental state in nature. It has been reported that the total fluoride concentration in seawater $1.3 \mathrm{mg} / \mathrm{liter} .^{1} \mathrm{In}$ places rich in fluoride-containing minerals, well water may contain up to about $10 \mathrm{mg} /$ liter of fluoride. The highest natural level reported is $2800 \mathrm{mg} / \mathrm{liter}$. Fluorides may go to a river as a result of industrial discharges. ${ }^{1}$ Human saliva is a mouth fluid over $99.5 \%$ being made up of water, which has many functions. It is involved in homeostasis and has a vital role in maintaining oral health., ${ }^{2,3}$ In humans, salivary glands can be divided into two main types, the major and minor salivary glands. The major salivary glands are parotid, sublingual, and submandibular. Minor salivary glands are the von Ebner glands and Blandin-Nuhn mucous glands. ${ }^{4}$ The composition of saliva varies according to the mucous or serous component of the glands. ${ }^{5}$ Therelative contribution from each type of gland to the total unstimulated saliva secretion varies as follows, $65 \%$ for submandibular, $23 \%$ parotid, $8 \%$ von Ebner, and $4 \%$ sublingual. ${ }^{6}$ Healthy adult subjects produce approximately $0.5 \mathrm{ml} /$ min, which is $500-1500 \mathrm{ml}$ of saliva per day. Several physiological and pathological factors can affect saliva secretion in both qualitative and quantitative term such as taste stimulation, smell, chewing, age, drugs, oral hygiene, physical exercise,

${ }^{1}$ Department of Clinical Biochemistry, College of Health Sciences, Hawler Medical University, Erbil, I raq.

2 Department of Clinical Biochemistry, College of Medicine, Hawler Medical University, Erbil, I raq.

${ }^{3}$ Lecturer at School of Biological and Marine Sciences, Faculty of Science and Engineering, Plymouth University, Plymouth, UK. * Correspondence: kwestan.muhammad@hmu.edu.krd 
psychological state, and hormone status. The type of saliva is different according to the type of salivary gland, with differences in the concentration of ions, salts, and total protein. ${ }^{7}$ This study aimed to measure salivary fluoride after fluoride intake (after brushing using toothpaste) and measure the concentration of fluoride in tap water (groundwater and public water supplies) in Erbil city.

\section{Methods}

This study was carried out on healthy subjects only.

\section{Experimental design}

This cross-sectional study was carried out during the period of March to July 2016 at the Department of Clinical Biochemistry, College of Health Sciences, Hawler Medical University, Erbil, Iraq. All the laboratory work was done at the Medical Research Center, Hawler Medical University, Erbil, Iraq. Salivary fluoride and fluoride from different sources of tap water in Erbil city were measured by (Fluoride, Palintest) and Total Ionic Strength Adjustment Buffer (TISAB II), with CDTA, for Fluoride Analysis using Ion Selective Electrodes, Ricca Chemical Company. Measurements were carried out according to manufactured instruction. Forty five volunteers (20-25 years) were examined. On three different days, in the morning after overnight fasting before brushing teeth, the saliva of the subjects (healthy non-smoker adult) was taken before brushing teeth that was a baseline. After 10 and 20 minutes of brushing after using 1.5 - $2 \mathrm{gr}$ of the toothpaste and washing the mouth with water, saliva was taken in which the cotton pad was held under the tongue for 5 minutes. After that, samples were put in the freezer $-20 C^{\circ}$ until the day of analysis. Before measuring salivary fluoride, samples were centrifuged (mini spin (plus) eppendorf) for 5 minutes. The control was distilled water free of fluoride. For measuring fluoride in water in Erbil city, samples (groundwater and surface water) were taken in different places for ten different days. Briefly, a volume of $0.2 \mathrm{ml}$ of sample was added to eppendorf tubes followed by $0.8 \mathrm{ml}$ of reagent that was prepared according to manufactured instruction according (Fluoride, Palintest) kit. Tubes were mixed well and then incubated at $25 \mathrm{C}^{\circ}$ for 3 minutes. The absorbance at $570 \mathrm{~nm}$ was then measured in a spectrophotometer and compared to a calibration curve prepared using (0-5) mMsodium fluoride. Each measurement was carried out in triplicate. A relevant statement on permission and ethical practices was approved by the Research Ethics Committee in the College of Health Sciences, Hawler Medical University.

\section{Statistical analysis}

The data was presented as the mean of concentration $\pm \mathrm{SD}$. The different variables were compared to each other using paired $t$ test for Table 2 and $t$ test for Table 1. A $P$ value of $\leq 0.05$ was considered statistically significant.

\section{Results}

Data was gathered for 45 adults (mean age $22.5 \pm 1.11$ years old) who participated in this study. The mean salivary concentrations for the different collection times are shown in Table 1. The present study demonstrated that salivary fluoride concentration reached to peak after 10 minutes of brushing. Salivary fluoride level in adults after using 1.5 - 2 $\mathrm{gm}$ of the toothpaste, the fluoride levels increase $0.06 \mathrm{mg} / \mathrm{L}$ after 10 minutes of brushing then decreased by $0.03 \mathrm{mg} / \mathrm{L}$ after 20 minutes of brushing. Using toothpaste significantly increased salivary fluoride level as compared to a baseline level $(P=0.002)$. Saliva after overnight sleeping before brushing was used as a control (0.01 to $0.12 \mathrm{mg} / \mathrm{L})$. Table 1 shows the mean salivary fluoride concentration \pm SD values of baseline and after using toothpaste. The mean salivary fluoride significantly $(P=0.002)$ increased after 10 minutes $(0.125 \pm 0.012)$ and 20 minutes $(0.095 \pm 0.009)$ of brushing teeth. 
The fluoride level in the surface water was level in ground water for all the days of significantly higher $(P=0.001)$ than the measurement (Table 2).

Table 1: Salivary fluoride (mean $\pm S D$ ) measured before brushing teeth (baseline), after 10 minutes of brushing and after 20 minutes of brushing ( $n=45$ independent experiments).

\begin{tabular}{cccc}
$\begin{array}{c}\text { Salivary fluoride } \\
\text { Baseline (mg/L) }\end{array}$ & $\begin{array}{c}\text { Salivary fluoride } \\
\text { After 10 min of } \\
\text { brushing (mg/L) }\end{array}$ & $\begin{array}{c}\text { Salivary fluoride } \\
\text { After 20 min of } \\
\text { Brushing (mg/L) }\end{array}$ & $\boldsymbol{P}$ value \\
\hline $0.065 \pm 0.06$ & $0.125 \pm 0.012$ & $0.095 \pm 0.009$ & 0.002 \\
\hline
\end{tabular}

Table 2: Fluoride concentration was measured in drinking water (tap water) in different places in Erbil city ( $n=10$ different days).

\begin{tabular}{|c|c|c|c|}
\hline Day & $\begin{array}{l}\text { Fluoride of groundwater } \\
\text { ( } \mathrm{mg} / \mathrm{L}) \\
\text { Mean } \pm \text { SD }\end{array}$ & $\begin{array}{c}\text { Fluoride of surface } \\
\text { water supplies (mg/L) } \\
\text { Mean } \pm \text { SD }\end{array}$ & $P$ values \\
\hline Day 1 & $0.2 \pm 0.1$ & $0.4 \pm 0.01$ & \\
\hline Day 2 & $0.09 \pm 0.001$ & $0.45 \pm 0.01$ & \\
\hline Day 3 & 0.00 & $0.5 \pm 0.02$ & \\
\hline Day 4 & $0.09 \pm 0.029$ & $0.43 \pm 0.1$ & \\
\hline Day 5 & $0.06 \pm 0.011$ & $0.4 \pm 0.019$ & 0.001 \\
\hline Day 6 & $0.1 \pm 0.02$ & $0.41 \pm 0.01$ & \\
\hline Day 7 & $0.3 \pm 0.031$ & $0.39 \pm 0.1$ & \\
\hline Day 8 & $0.078 \pm 0.041$ & $0.45 \pm 0.02$ & \\
\hline Day 9 & $0.3 \pm 0.08$ & $0.5 \pm 0.03$ & \\
\hline Day 10 & 0.00 & $0.6 \pm 0.04$ & \\
\hline
\end{tabular}




\section{Discussion}

Tooth brushing with fluoride toothpaste can raise salivary fluoride. ${ }^{8}$ It has been reported that salivary fluoride level varies from 0.01 to $0.1 \mathrm{mg} / \mathrm{L}$ depending on the individual diet, water fluoride, and fluoride usage. ${ }^{9}$ Also, the concentration of salivary fluoride depends on many factors, such as dental products used for caries prophylaxis and fluoridated drinking water. Also, saliva can get fluoride via facilitated transport over membranes of salivary gland tissue. ${ }^{10}$ It has been reported that concentration of salivary fluoride bout $0.019 \mathrm{mg} / \mathrm{L}$ and confirmed that fluoride level in saliva was not depending on flow rates and high concentration of salivary fluoride can cause the formation of calcium fluoride. ${ }^{11,12}$ The concentration of fluoride in the saliva is only about $0.01 \mathrm{ppm}^{9}$. Although it has been shown that oral ingestion of 1 to $10 \mathrm{mg}$ of fluoride can cause an increase in salivary fluoride levels over about the following two hours, there appears to be little data on the relation of salivary fluoride concentration to the level of dietary fluoride intake at more normal levels of intake. The salivary fluoride concentration is determined by the intake fluoride to the mouth via drinking water, beverages, food, toothpaste, and mouth rinses. In addition, physiological factors such as the volume of saliva before and after swallowing and salivary flow rate can affect the elimination rate of fluoride. ${ }^{13}$ Also, It has been reported that salivary fluoride increased immediately after brushing teeth then dropped the baseline after 6 hours. ${ }^{14}$ The main natural source of fluoride is drinking water. Adding fluoride to public water supplies can prevent dental caries. Testing fluoride level in drinking water (public water supplies and groundwater) of different places in Erbil city was the second purpose of this study. In this research have been found that in places that the tap water is groundwater, that the fluoride level is very low in some days has not been detected $(P<0.05)$. The samples have been collected in 10 different days, and then measuring fluoride by different kits(Total Ionic Strength Adjustment Buffer (TISAB II), with CDTA, for Fluoride Analysis using lon Selective Electrodes, Ricca Chemical Company, and Fluoride, Palintest kit). The government should be more concerned about it because it leads to the threat of dental caries that affects human health. It has been published that fluoride concentration in drinking water bout $1 \mathrm{mg} / \mathrm{L}$ can help prevent dental caries and also has been shown cause dental mottle and adverse effects on bone. ${ }^{15,16}$

\section{Conclusion}

Tap water is usually the main source of drinking water and fluoride intake. The fluoride levels in tap water is really important in determining total fluoride exposure. It has been proven that saliva contains fluoride, and the results of the current study have shown that toothpaste can increase salivary fluoride temporarily. That assumes fluoride might be absorbed in the mouth, so further studies are required to understand the exact mechanism. It would be important to determine the fluoride concentration in natural sources (tap water) that might be affected of fluoride benefit that caused by excess or less fluoride intake in Erbil city.

\section{Competing interests}

The authors declare that they have no competing interests.

\section{References}

1. Sloof, W, Eerens H, Janus J, Ros J. Integrated criteria document: Fluorides; 1989. (Report No. 758474010). Bilthoven: National Institute of Public Health and Environmental Protection. (Accessed March 1, 2017, at http://www.rivm.nl/ bibliotheek/rapporten/758474010.pdf).

2. Amerongen VAN, Bolscher AJ, Veerman E. Salivary proteins: Protective and diagnostic value in cardiology? Caries Research 2004; 38:247-53.

3. Lawrence HP. Salivary markers of systemic disease: non-invasive diagnosis of disease and monitoring of general health. J Can Dent Assoc 2002; 68(3):170-4.

4. Carranza M, Ferraris ME, Galizzi M. Structural and morphometrical study in glandular parenchyma from alcoholic sialosis. J Oral Pathol Med 2005; 34(6):374-9. 
5. Hu S, Denny P, Xie Y, Loo JA, Wolinsky LE, $\mathrm{Li} Y$ et al. Differentially expressed protein markers in human submandibular and sublingual secretions. Int J Oncol 2004; 25(5):1423-30.

6. Schipper RG, Silletti E, Vingerhoeds $\mathrm{MH}$. Saliva as research material: Biochemical, physicochemical and practical aspects. Arch Oral Biology 2007; 52(12):1114-35.

7. Aps JKM, Martens LC. Review: The physiology of saliva and transfer of drugs into saliva. Forensic Science International 2005; 150(2-3):119-31.

8. Duckworth RM, Morgan SN, Gilbert RJ. Oral fluoride measurements for estimation of the anti-caries efficacy of fluoride treatments. J Dent Res 1992; 71(Spec No):836-40.

9. Lagerlof $F$, Oliveby A. Caries-protective factors in saliva. Adv in Dent Res 1994; 8(2):229-38.

10. Ole Fejerskov and Edwina Kidd. Dental Caries: The Disease and Its Clinical management. $2^{\text {nd }}$ ed. Blackwell Publishing; 2008. P.38.

11. Oliveby A, Lagerlof F, Ekstrand J, Dawes C. Studies on fluoride concentrations in human submandibular/sublingual saliva and their relation to flow rate and plasma fluoride levels. J Dent Res 1989; 68(2):146-9.

12. Dawes C, Weatherell J. Kinetics of fluoride in the oral fluids. J Dent Res (Spec Issue) 1990; 69:638 -44 .

13. Lagerlof F, Oliveby A, Ekstrand J. Physiological factors influencing salivary clearance of sugar and fluoride. J Dent Res 1987; 66(2):430-5.

14. Naumova EA, Kuehnl P, Hertenstein P, Markovic L, Jordan RA, Gaengler $P$, et al. Fluoride bioavailability in saliva and plaque. BMC Oral Health 2012; 12:3.

15. Alarcon-Herrera MT, Martin-Dominquez I, Trejo-Vazquez R, Rodriquez-Dozal S. Well water fluoride, dental fluorosis, bone fractures in the Guadiana Valley of Mexico. Fluoride 2001; 34(2):139-49.

16. Kurttio P, Gustavsson N, Vartiainen T, Pekkanen $J$. Exposure to natural fluoride in well water and hip fracture: A cohort analysis in Finland. Am J Epidemiol 1999; 150(8):817-24.

17. Burt BA. The changing patterns of systemic fluoride intake. J Dent Res 1992; 71(5):1228-37. 